\title{
Cercopithecoid humeri from Taung support the distinction of major papionin clades in the South African fossil record
}

\author{
Christopher C. Gilbert ${ }^{1-3^{*}}$, Maressa Q. Takahashi ${ }^{3,4}$, and Eric
}

Delson $^{2,3,5,6,7}$

${ }^{1}$ Department of Anthropology, Hunter College of the City University of New York, 695

Park Avenue, New York, NY 10065, USA

${ }^{2} \mathrm{PhD}$ Program in Anthropology, the Graduate Center of the City University of New

York, 365 Fifth Avenue, New York, NY 10016, USA

${ }^{3}$ New York Consortium in Evolutionary Primatology, New York, NY, USA

${ }^{4}$ Department of Ecology, Evolution, and Environmental Biology, Columbia University, 1200 Amsterdam Avenue, New York, NY 10027, USA

${ }^{5}$ Department of Anthropology, Lehman College of the City University of New York, 250

Bedford Park Boulevard West, Bronx, NY 10468, USA

${ }^{6}$ Department of Vertebrate Paleontology, American Museum of Natural History, 200

Central Park West, New York, NY 10024, USA

${ }^{7}$ Institut Català de Paleontologia Miquel Crusafont (ICP), Universitat Autònoma de

Barcelona, Edifici Z (ICTA-ICP), campus de la UAB, c/ de les Columnes, s/n., 08193

Cerdanyola del Vallès (Barcelona), Spain

*To whom correspondence should be addressed: cgilbert@hunter.cuny.edu, ccgilbs@gmail.com

Key Words: phylogeny, Procercocebus, Theropithecus, Mandrillus, Cercocebus,

Lophocebus, Papio izodi, Parapapio 


\begin{abstract}
Associated cercopithecoid postcrania are rare in the Plio-Pleistocene fossil record, particularly in the case of South African karst cave sites. However, as clear postcranial differences between major papionin clades have been documented, it should be possibile to assign isolated papionin postcrania to the Cercocebus/Mandrillus and Papio/Lophocebus/Theropithecus groups wherever sufficient anatomy is preserved. Here, we demonstrate that two partial humeri preserved at Taung, UCMP 56693 and UCMP 125898, are most likely attributable to the Cercocebus/Mandrillus and Papio/Lophocebus/Theropithecus clades, respectively. Univariate analyses (ANOVAs and $t$-tests) and multivariate analyses (discriminant function analyses) of humeral features, combined with a phylogenetic analysis of 24 humeral characters, all support our assessment. Given that the overwhelming number of craniodental specimens at Taung are attributable to two papionin taxa, Procercocebus antiquus (a member of the Cercocebus/Mandrillus clade) and Papio izodi (a purported fossil species of the modern genus Papio), we assign UCMP 56693 to Pr. antiquus and UCMP 125868 to P. izodi with a high degree of confidence. Implications for cercopithecoid evolution and biogeography are discussed, with a particular emphasis on these two fossil taxa.
\end{abstract}




\section{Introduction}

Associated postcranial fossils are crucial to fully understand the functional morphology, locomotor adaptations, phylogenetic relationships, and evolutionary history of extinct taxa. Unfortunately, primate postcrania associated with identifiable craniodental material are rare in the fossil record. Although cercopithecoid monkeys are relatively common elements of the Plio-Pleistocene fauna, there are still a number of taxa for which postcranial specimens cannot be confidently attributed, particularly at South African cave sites. Due to the depositional and preservational environment in karstic caves such as Taung, Sterkfontein, Makapansgat, and Swartkrans, craniodental and postcranial material of multiple individuals and multiple taxa are often jumbled loosely or in the same collected block such that elements found in close proximity cannot be assumed to be associated and are often demonstrably not associated (e.g., the large block of breccia from Taung illustrated by Freedman, 1965). Thus, in the vast majority of cases, postcranial remains cannot be unequivocally attributed to identifiable cranial remains (e.g., Ciochon, 1994; Elton, 2001). Because many taxa found in the South African Plio-Pleistocene are thought to be primitive African papionin monkeys (Subtribe Papionina, sensu Strasser and Delson, 1987), much of the early locomotor history of this highly successful group of primates remains obscured.

In addition to the taphonomic issues involved in associating isolated postcrania at the various Plio-Pleistocene South African cave sites, the task of assigning postcrania to taxon has been previously hampered by the complicated history of African papionin phylogenetic interpretations (e.g., Barnicot and Wade, 1970; Barnicot and HewettEmmett, 1972; Cronin and Sarich, 1976; Hewett-Emmett et al., 1976; Szalay and Delson, 
1979; Strasser and Delson, 1987; Delson and Dean, 1993; Disotell et al., 1992; Disotell, 1994, 2000; Harris and Disotell, 1998; Tosi et al., 2000, 2003). Among extant African papionins, a major revision in our understanding of phylogenetic relationships has occurred over the last 20 years. Historically, morphological comparisons grouped Cercocebus and Lophocebus in one group (the mangabeys) and Mandrillus and Papio in another group (the baboons), with Theropithecus (the geladas) either belonging with the Mandrillus/Papio group or as the sister taxon to both groups (Szalay and Delson, 1979; Strasser and Delson, 1987; Delson and Dean, 1993). However, more recent molecular and morphological work has revised these relationships, strongly suggesting that 1) Cercocebus forms a monophyletic group with Mandrillus, and 2) Lophocebus, Papio, Theropithecus, and the newly discovered Rungwecebus are all members of a single clade that is sister to the Cercocebus/Mandrillus group (Fig. 1; Disotell et al., 1992; Disotell, 1994, 2000; Harris and Disotell, 1998; Fleagle and McGraw, 1999, 2002; Tosi et al., 2000, 2003; Davenport et al., 2006; Gilbert, 2007; Olson et al., 2008; Burrell et al., 2009; Zinner et al., 2009; Gilbert et al., 2009; 2011; Roberts et al., 2010; Guevara and Steiper, 2014). Fleagle and McGraw $(1999,2002)$ have shown that postcranial elements are highly diagnostic of the Cercocebus/Mandrillus and Papio/Lophocebus/Theropithecus clades (no adult skeletal specimens yet exist for the kipunji, Rungwecebus--see Davenport et al., 2006; Gilbert et al., 2011), suggesting that fossil postcrania from one of these two phylogenetic groups should be recognizable as well.

In fact, even in the absence of associated partial skeletons, it may still be possible to attribute isolated primate postcrania to craniodental material in certain cases. For example, if one taxon represents the vast majority of fossil primate craniodental 
specimens at a given site, it may be reasonable to assume on general probability grounds that the majority of isolated primate postcranial specimens found at that site are also attributable to the same taxon (provided the postcranial specimens are within the same general size range as the craniodental material). Another straightforward group of cases involves the distinction of two or more fossil primate taxa of vastly differing size classes or previously established locomotor groups, again making postcranial attribution relatively straightforward on general size grounds, locomotor distinction, or both. Yet a third possibility occurs wherever phylogenetic relationships are well-established among fossil primate taxa at a given site. In these cases, it may also be possible to attribute isolated postcrania to individual taxa provided that phylogenetically informative postcranial features have been previously identified among the taxa in question. For example, at many sites where both adapoid and omomyoid primates are found, in addition to general size differences, isolated postcrania may be attributed to one group or the other on the basis of phylogenetically correlated features associated with their strepsirrhine or haplorhine affinities, respectively (e.g., see Beard et al., 1988; Dagosto et al., 1999; Gebo et al., 2001; 2012; Dunn et al., 2006; Rose et al., 2009; Dunn, 2010; etc.). Finally, all of the above lines of reasoning may be used separately or in some combination to identify isolated primate postcrania.

Two fossil humeri from the southern African Plio-Pleistocene site of Taung provide an excellent test case and opportunity to investigate whether unassociated cercopithecoid postcranial specimens can be assigned with confidence to genus and species. Much of the craniodental material at Taung has been identified to either Procercocebus antiquus (hypothesized to be a member of the Cercocebus/Mandrillus 
clade [e.g., Gilbert, 2007, 2013]) or Papio izodi (most likely to be a member of the Papio/Lophocebus/Theropithecus clade, as generally suggested by its taxonomic attribution [e.g., Freedman, 1957; Szalay and Delson, 1979; Jablonski, 2002; Jablonski and Frost, 2010]). Given the high probability, based on craniodental representation, that the papionin postcranial material at Taung belongs to one of these two taxa, and also because of the diagnostic features evident in the postcrania of modern members of the African papionin clades (Fleagle and McGraw, 1999, 2002), the isolated humeri at Taung should potentially be assignable to one of these two extinct taxa. Assigning this previously unidentified and unassociated postcranial material at Taung is important for addressing the notable gap in our knowledge of papionin and cercopithecoid postcranial evolution; for example, secure taxonomic attributions would provide new information regarding the functional morphology of the Taung papionin taxa as well as the overall pattern of African papionin locomotor evolution. In addition, taxonomic identification of postcranial material, along with the careful and detailed study of postcranial morphology, may ultimately help to shed light on African papionin phylogenetic relationships, particularly in combination with already established craniodental features.

\section{The Taung cercopithecoids}

Fossil mammals were first recovered from lime workings at Taung before 1910 (see Haughton, 1925; Gear, 1958). At that time, specimens were deposited in the Cape Town Museum (now Iziko South African Museum). Following Dart's (1925) recognition of Australopithecus africanus, additional fossils were collected for the Department of Anatomy, University of the Witwatersrand Medical School (UWMA, Johannesburg) and 
the Transvaal (now Ditsong) Museum (Pretoria). In 1947-1948, the University of California South African Expedition under the direction of C. L. Camp collected fossils at Taung, Bolt's Farm and other smaller localities. The geology was described and interpreted by F. Peabody (1954), and the fossils were deposited in the University of California Museum of Paleontology (UCMP, Berkeley), with a selection transferred to UWMA per agreement with R. Broom. Freedman (1965) described a number of primate specimens from this collection.

In 1968, ED borrowed the majority of the primates for further preparation and study in New York. The specimens analyzed in this paper were among the smaller blocks prepared with acetic acid following the technique of Freedman (1957) and others. Each of the blocks contained two fossils, a partial mandible and a partial humerus. Both pairs of fragments fit together to yield a well-preserved mandibular corpus with almost all teeth (UCMP 56658) and a humerus lacking the proximal end (UCMP 56693), discussed below. The large block of breccia illustrated by Freedman (1965), UCMP 56831, yielded numerous crania and mandibles but only one relatively well-preserved postcranial element, a partial humerus now numbered UCMP 125868.

Freedman (1957) recognized two papionin taxa at Taung to which most cercopithecoid craniodental specimens were referred: Parapapio antiquus (Haughton, 1925) and Papio izodi Gear, 1926. Freedman (1961) described an additional putatively distinct species Papio wellsi, but most later authors have considered this a junior subjective synonym of $P$. izodi (following e.g., Szalay and Delson, 1979; Gilbert 2013). Gilbert (2007) made Pp. antiquus the type species of his new genus Procercocebus, recognizing numerous craniodental features in common with the extant Cercocebus (and 
Mandrillus) but strongly differing from other species included in Parapapio. Papio izodi has traditionally been regarded as an early ancestor of the modern baboon (e.g., Freedman, 1957; Szalay and Delson, 1979; Jablonski, 2002; Jablonski and Frost, 2010), although Gilbert (2013) has suggested that it may, in fact, be a late stem papioninan rather than a member of the extant genus. Whatever their phyletic affiliations, $P r$. antiquus and $P$. izodi include the overwhelming majority of taxonomically identifiable cercopithecoid craniodental remains found at Taung (Freedman, 1957; Szalay and Delson, 1979; Gilbert, 2007, 2013; Jablonski and Frost, 2010), and thus it is likely that most cercopithecoid postcrania found there are also attributable to one of these two papionin taxa.

\section{This Study}

In this study, we examine the two fossil cercopithecoid humeri from the University of California Museum of Paleontology (UCMP) Taung collection that appear to be papionins. Preliminary examination of these two humeri suggests that they represent different species and most probably different sexes, with one humerus being more robust in muscle markings, bony processes, and overall shape/size (UCMP 56693, a presumed male), and the other being more gracile (UCMP 125868, a presumed female). Specifically, we analyze morphological characteristics present in each fossil humerus, both quantitative and qualitative, and compare these features to those observed in extant papionins to determine whether each of these two Taung fossil humeri may be categorized as more similar to the Cercocebus/Mandrillus group or the 
Papio/Lophocebus/Theropithecus group. If such distinctions can be made, it may be possible to assign the humeri more specifically to Pr. antiquus and/or P. izodi.

\section{Materials and Methods}

For this study, we measured and scored 58 papionin humeri from the collections housed in the American Museum of Natural History (AMNH) in New York City, the Smithsonian Institution National Museum of Natural History in Washington, D.C. (USNM), and the Harvard Museum of Comparative Zoology in Cambridge, MA (MCZ) (see Table 1). Only wild-shot and non-pathological zoo specimens were included, and among those, we restricted our sample to specimens with fused epiphyses, although humeri with visible epiphyseal lines were incorporated to increase sample sizes. Measurements were taken on the right humerus whenever possible. In addition, we made observations and measurements on the original UCMP Taung fossil specimens as well as casts of the Taung specimens from ED's research collection (Table 1). Theropithecus was largely excluded from our study because no Theropithecus craniodental material is known from Taung, making a taxonomic assignment of either fossil humerus to Theropithecus highly unlikely. However, two Theropithecus gelada humeri (one male and one female) housed at the AMNH were examined and scored in order to include Theropithecus in a small cladistic analysis of humeral morphology.

We used a mixture of both quantitative measurements and qualitative observations on all specimens, largely based on those characteristics identified by Fleagle and McGraw (1999, 2002) as significant in demarcating the Cercocebus/Mandrillus clade 
from the Papio/Lophocebus/Theropithecus clade. All measurements were taken using digital calipers and recorded to the nearest tenth of a millimeter.

In total, we examined 10 different traits. Six were quantitative: anterior articular width of the humerus, olecranon fossa width, anteroposterior (AP) depth of the distal humerus, maximum width across the deltoid plane in anterior view, supinator crest maximum length, and brachialis crest maximum width in posterior view (see Table 2; Fig. 2). In addition, four features were assessed qualitatively: relative extension of supinator crest on humerus (does not extend proximally $=1$ or extends proximally $=2$ ), height of lateral margin of olecranon fossa (short $=1$ or tall $=2$ ), olecranon fossa depth $($ shallow $=1$ or deep $=2)$, and shape of olecranon fossa $($ rounded $=1$ or triangular $=2)$ (see Table 3). One of these (relative extension of supinator crest) is seemingly redundant with the quantitative measurement of supinator crest height; however, because we could not scale our quantitative measure relative to overall humeral length in this study (both fossil humeri lack the proximal ends), we felt that our quantitative measurement often failed to accurately capture the clear differences observed in this feature. Accordingly, we scored it qualitatively as well (see also Fleagle and McGraw, 1999, 2002). The three traits of olecranon shape were added to better express distinctions in this feature implied by the work of Fleagle and McGraw (2002).

To account for size (and in light of the missing proximal end of both fossils), we calculated the geometric mean (GM) from the six quantitative measurements listed above plus two other standard measurements available on all extant and fossil specimens (anteroposterior diameter of the humerus approximately at midshaft and biepicondylar width of the humerus) for a total eight-measurement GM representing the size of each 
humeral specimen. For each specimen, we then divided the six quantitative measurements of interest by the GM to calculate six indices (Mosimann shape variables, see Jungers et al., 1995) comparable to indices calculated previously by Fleagle and McGraw (1999, 2002): relative articular width (anterior articular width of humerus/GM), relative olecranon fossa width (olecranon fossa width/GM), relative AP articular depth (distal anteroposterior depth/GM), relative deltoid plane width (maximum width across deltoid plane in anterior view/GM), relative supinator length (supinator crest maximum length/GM), and relative brachialis width (brachialis maximum width in posterior view/GM). Because allometric scaling is known to be a significant factor in papionin morphological analyses (e.g., Gilbert and Rossie, 2007; Gilbert et al., 2009), we also computed the correlation between all six indices and the corresponding GM for each specimen (using Pearson's $r$ ) to test for allometric effects. All statistical analyses were performed in SPSS 20.

The first set of analyses was univariate. In order to replicate the results of Fleagle and McGraw (1999, 2002), we pooled data for each clade (Cercocebus/Mandrillus versus Papio/Lophocebus) and tested each relative quantitative measurement for significance using $t$-tests. In addition, we also tested each clade relative to a sample of macaques to assess significant differences relative to the presumed primitive papionin morphotype using an ANOVA with post-hoc comparisons (Tukey's HSD for equal variances and Games-Howell for unequal variances). To increase sample size and keep consistency across studies, we combined data into a pooled-sex sample, as in Fleagle and McGraw's studies (1999, 2002), in addition to sex-specific analyses. In summary, we tested each of 
the six relative measurements for the $C / M$ clade, $P / L$ clade, Macaca sample, and two Taung humeri. We conducted these tests three times, each time testing males-only, females-only, and pooled-sex. For qualitative characters, Mann-Whitney $U$-tests were conducted between the extant papionin clades after assigning values of 1 or 2 to each character state for each specimen (Table 3).

The second set of analyses was multivariate, utilizing discriminant function analyses (DFA). Because the fossil humeri cannot be assigned to sex with absolute certainty, discriminant function analyses were employed including all specimens (male and female), one set assigning three groups (Cercocebus/Mandrillus, Papio/Lophocebus, and Macaca) and a second set of DFAs with the Cercocebus/Mandrillus and Papio/Lophocebus groups, but with macaques excluded. A third set was run assigning five groups corresponding to each individual genus (Cercocebus, Mandrillus, Papio, Lophocebus, and Macaca). A final set was run with the groups by genus, but with macaques excluded. In each set, two analyses were performed, one using the six quantitative relative measurements plus the geometric mean, and one using those seven values plus the four qualitative scores as well. In total, we ran eight DFAs. While including non-continuous (i.e., qualitative) data violates some statistical assumptions, DFA is usually considered robust enough to include a small number of non-continuous variables (e.g., Lachenbruch, 1975; Klecka, 1980; Tabachnick and Fidell, 1996; Gordon and Wood, 2013). For those who prefer continuous variables only, both analyses are included. Prior probabilities for each analysis were calculated on the basis of group size (rather than assuming equal groups). 
In addition to DFAs, we also conducted a small combined-sex (i.e., male + female concatenated matrix; see Gilbert et al., 2009, 2013) phylogenetic analysis based on 24 total characters, 22 specific humeral characters (11 for each sex) and two body size characters (the male and female geometric means), including the fossil humeri as separate operational taxonomic units (OTUs). A full list of characters and character states is given in Table 4. The final data matrix is provided in the Supplementary Online Material (SOM). An exhaustive search was conducted in PAUP 4.10b (Swofford, 2003) with Macaca assigned as the outgroup. For assessing levels of clade support, decay indices were calculated along with a 10,000 replication branch and bound bootstrap analysis with replacement.

\section{Results}

Morphological comparisons and boxplots (Figs. 3-7) illustrate the distributions of the humeral shape indices, with mean values for each taxon and results from the $t$ tests/ANOVAs presented in Table 5. Of the six relative measurements examined in this study, only one was significantly correlated with size (i.e., allometrically influenced): the relative width of the olecranon fossa $(r=-0.43, p<0.01)$. Despite using slightly different indices based on the geometric mean, the results of the $t$-tests/ANOVAs corroborate the previous results of Fleagle and McGraw (1999, 2002). Thus, compared with Papio and Lophocebus, Cercocebus and Mandrillus possess humeri with significantly expanded deltoid planes (males and pooled-sex), significantly narrower articular surfaces (males and pooled-sex), significantly wider brachialis flanges (males and pooled-sex), and significantly narrower olecranon fossae (males, females, and pooled-sex) (Table 5; Figs. 
3-7). While we were unable to detect a significant difference in relative supinator crest length as expressed over the geometric mean, our qualitative scoring system confirmed Fleagle and McGraw's $(1999,2002)$ observation that Cercocebus and Mandrillus possess supinator crests that are significantly more proximally extended than Papio and Lophocebus (indeed, this was one of the most consistent and obvious differences between taxa; males, females, and pooled-sex) (Table 5; Figs. 3-7). Qualitative scoring also revealed that Cercocebus and Mandrillus display significantly deeper and more triangular-shaped olecranon fossae with significantly taller lateral walls compared to Papio and Lophocebus (males and pooled-sex comparisons, only; Table 5, Figs. 3-7). Comparisons between Cercocebus/Mandrillus and Macaca reveal no significant differences in the quantitative indices or qualitative characters, indicating that in many aspects of the humerus Cercocebus and Mandrillus probably retain the primitive condition for papionins (see also Fleagle and McGraw, 1999, 2002). However, the fact that comparisons between Macaca and Papio/Lophocebus are significantly different for only one quantitative index in the pooled-sex and male comparisons (relative olecranon fossa width) suggests that macaques are variable and probably intermediate in some respects of their anatomy (see also boxplots; Figs. 5-7); some of the significance values (or lack thereof) may, in fact, be due to a relatively small sample size.

Looking at UCMP 56693 and UCMP 125868 in the boxplot comparisons (Figs. 57), UCMP 56693 plots within the Cercocebus/Mandrillus range (including outliers) for all significant relative measures and plots outside of the Papio/Lophocebus range for relative articular width, relative olecranon fossa width, and relative deltoid plane width. In addition, UCMP 56693 displays a proximally extended supinator crest as well as a 
deep and triangularly shaped olecranon fossae, character states most consistent with the Cercocebus/Mandrillus clade (Table 5; Figs. 3-7). Conversely, UCMP 125868 consistently plots within the Papio/Lophocebus range and falls outside of the Cercocebus/Mandrillus range for relative olecranon fossa width. Qualitatively, UCMP 125868 displays an unextended supinator crest along with a shallow and rounded olecranon fossa, character states again most consistent with the Papio/Lophocebus clade (Table 5; Figs. 3-7).

The DFA of all specimens including the six relative quantitative humeral measures and the geometric mean correctly classifies $93.9 \%$ of specimens to either the Cercocebus/Mandrillus group or the Papio/Lophocebus group, with 91.8\% correctly classified during cross-validation (Fig. 8a, see Table 6 for full DFA results). Including the four qualitative measures in a second DFA improves the classification values to $100 \%$ correct in the original classification and 95.9\% in the cross-validation (Fig. 8b, Table 6). In both analyses, UCMP 56693 is classified as a member of the Cercocebus/Mandrillus group and UCMP 125868 is classified as a member of the Papio/Lophocebus group, both with high posterior probabilities (Fig. 8a-b). When Macaca is included in the quantitative measures-only DFA, $87.9 \%$ of specimens are correctly classified to the Cercocebus/Mandrillus, Papio/Lophocebus, and Macaca groups with 74.1\% of specimens correctly classified during cross-validation; when Macaca is included in the quantitative plus qualitative DFA analyses, $91.4 \%$ of specimens are correctly classified to the Cercocebus/Mandrillus, Papio/Lophocebus, and Macaca groups with $82.8 \%$ of specimens correctly classified during cross-validation. UCMP 56693 and UCMP 125868 
are again classified as members of the Cercocebus/Mandrillus and Papio/Lophocebus groups, respectively, with high posterior probabilities (Fig. 8c, Table 6).

To further examine possible morphological similarities in the fossil humeri we also ran DFA analyses using the same sets of variables, but separating individual genera (Cercocebus, Mandrillus, Papio, Lophocebus) (see Fig. 9 and Table 6). In these cases, classification values are generally high with UCMP 56693 classified as a member of either the Cercocebus group or Mandrillus group with high posterior probabilities, and UCMP 125868 classified as a member of the Papio group or Lophocebus group with high posterior probabilities (Fig. 9a, Table 6). Results are essentially the same when Macaca is included in the analyses (Fig. 9d, Table 6).

Finally, a cladistic analysis of 24 humeral characters results in three most parsimonious trees (MPTs), summarized in Figure 10 (for the complete character matrix and individual MPTs, see SOM 1 and 2). In all MPTs, UCMP 56693 is reconstructed as a member of the Cercocebus/Mandrillus clade, specifically as the sister to Mandrillus, while UCMP 125868 is reconstructed as a member of the Lophocebus/Papio/Theropithecus clade, closest to Papio and Theropithecus. Bootstrap values placing the fossil specimens within the $C / M$ and $P / L / T$ clades are high $(70 \%$ or above), but while bootstrap values supporting a UCMP 56693/Mandrillus clade are moderate (67\%), any support for a specific position of UCMP 125868 within the $P / L / T$ grouping is below 55\%. Decay indices also suggest support is weakest for the clade containing Papio, Theropithecus, and UCMP 125868, but support is similar for the broader C/M/UCMP 56693 and P/L/T/UCMP 125868 groupings. 


\section{Discussion}

The results of this study strongly suggest that UCMP 56693 and UCMP 125868 can be confidently assigned to the Cercocebus/Mandrillus and Papio/Lophocebus/Theropithecus clades, respectively. The results of the ANOVAs, DFAs, and cladistic analysis all independently suggest that both humeri are individually attributable to these clades; thus, given that the most common cercopithecoid craniodental specimens at Taung are recognized as Pr. antiquus (an early member of the Cercocebus/Mandrillus clade) and $P$. izodi (a possible early member of the Papio/Lophocebus lineage), we suggest that UCMP 56693 is a humerus of Pr. antiquus and UCMP 125868 is a humerus of $P$. izodi. Furthermore, as no postcrania have been previously attributed to any South African fossil cercopithecoid with any certainty (see Ciochon, 1994 and Elton, 2001 for earlier attempts), these specimens represent the first window into the postcranial evolution of the Cercocebus/Mandrillus and Papio/Lophocebus clades in the South African fossil record.

Our analyses support the previous work of Fleagle and McGraw $(1999,2002)$ and note numerous significant differences in humeral morphology between the Cercocebus/Mandrillus and Papio/Lophocebus groups, particularly in the male and pooled-sex comparisons. As previously noted by multiple authors (Nakatsukasa, 1994a, 1994b, 1996; Fleagle and McGraw, 1999, 2002; Gilbert, 2007, 2013; Gilbert and Rossie, 2007; Gilbert et al., 2009), male papionins are more distinctive than females in their overall skeletal anatomy, and so the clearest differences are often noted in the male and pooled-sex analyses. Similar to Fleagle and McGraw (1999, 2002), we also note that the Cercocebus/Mandrillus group resembles Macaca in most quantitative measurements, and 
that this may suggest that Cercocebus, Mandrillus, and Procercocebus retain morphologies closer to the ancestral condition compared to the Papio/Lophocebus group, which appears to be more derived. Recent mitochondrial DNA studies have suggested that Mandrillus/Cercocebus plus Macaca together may form the sister clade to Papio/Lophocebus/Theropithecus/Rungwecebus (Finstermeier et al., 2013; Pozzi et al., 2014; Liedigk et al., 2014), so it is possible that our results instead reflect a close phylogenetic relationship between macaques, Mandrillus, Cercocebus, and Procercocebus. However, we view the mtDNA trees with much skepticism, more likely indicative of a complex and rapid branching history involving mitochondrial introgression and incomplete lineage sorting among papionin taxa (e.g., see Guevara and Steiper, 2014). Since the preponderance of morphological and molecular evidence, particularly that from nuclear DNA, supports the position of macaques as the basal extant papionin taxon, sister to a clade containing all African papionins (e.g., Harris and Disotell, 1998; Harris, 2000; Xing et al., 2005; Perelman et al., 2011; Springer et al., 2012), we view this as the best supported phylogenetic hypothesis and therefore consider any similarities between macaques and African papionin taxa as likely symplesiomorphies (or potential homoplasies/parallelisms). This interpretation is further supported by the fact that primitive cercopithecoids such as Victoriapithecus also appear to share humeral characters with Macaca, Cercocebus, Procercocebus, and Mandrillus (Gilbert et al., 2010).

Thus, while there is overlap between macaques and the Cercocebus/Mandrillus clade, our analyses also demonstrate that Cercocebus and Mandrillus are likely to be derived relative to macaques in numerous aspects of their overall humeral morphology, 
and subtle differences are probably masked in the ANOVAs as an artifact of small sample size. This is evident in the direction of the boxplots as well as the DFAs (which are highly accurate in separating all three groups). With a slightly greater sample size, Fleagle and McGraw (2002) pointed to a few instances where Cercocebus and Mandrillus appear derived, specifically in the relative distal articular width and the prominence of the medial trochlear lip. In both of these features, UCMP 56693 is closest to the mean condition seen in Mandrillus and Cercocebus (see Figs 3-6; Table 5), suggesting that it is indeed derived towards these extant taxa and not simply reflecting the primitive condition for African papionins.

In total, these analyses suggest that UCMP 56693, and Procercocebus by extension, was adapted for powerful forelimb/elbow flexion and possessed a narrow, stable elbow joint. In addition, the posteriorly directed medial epicondyle suggests a semi-terrestrial/terrestrial animal (Fig. 11). Thus, we interpret UCMP 56693 as evidence that Procercocebus likely engaged in behaviors similar to those of modern Cercocebus and Mandrillus, and that the features in the humerus most likely relate to powerful manual foraging activities on the ground or forest floor (Fleagle and McGraw, 2002). Furthermore, despite numerous craniodental resemblances to Cercocebus torquatus among extant taxa (see, e.g., Eisenhart, 1974; Gilbert, 2007, 2013), the morphology of the UCMP 56693 humerus (particularly the posterior orientation of the medial epicondyle) suggests that Pr. antiquus was likely more terrestrially adapted than $C$. torquatus. Indeed, the few C. torquatus humeri we examined did not display medial epicondyles as posteriorly oriented as in UCMP 56693. This might in turn support Cooke's (2012) hypothesis that the more arboreal behavior seen in extant C. torquatus 
represents a derived adaptation relative to the common ancestor with Mandrillus and other Cercocebus mangabeys, despite the fact that C. torquatus appears to retain primitive craniodental features consistent with its likely position as the most basal crown Cercocebus taxon (Gilbert, 2007; Perelman et al., 2011; Guevara and Steiper, 2014; DeVreese and Gilbert, 2015). Thus, Pr. antiquus displays a mosaic of morphologies, with craniodental features generally similar to $C$. torquatus but forelimb features more similar to Mandrillus, providing yet another line of evidence supporting its generic distinctiveness and possibly providing more information about the Cercocebus/Mandrillus primitive condition.

Also similar to Fleagle and McGraw (1999, 2002), our analyses suggest that Papio and Lophocebus are postcranially derived relative to the primitive condition exhibited by macaques. UCMP 125868 clearly resembles extant members of Papio/Lophocebus in nearly all analyses and represents some of the first solid evidence that $P$. izodi at Taung may be a derived member of this clade rather than a more primitive stem African papionin. While $P$. izodi craniodental material retains many primitive features relative to extant Papio and Lophocebus (see Gilbert, 2013; Gilbert et al., 2013; Gilbert et al., 2015), UCMP 125868 is derived towards Papio and Lophocebus humeri in nearly every respect: a wider articular width, an unexpanded deltoid plane, an unextended supinator crest, a wider olecranon fossa, and a shallower and rounder olecranon fossa. One caveat, however, is that UCMP 125868 displays some damage on the medial side of the distal articular surface, with the medial epicondyle and medial trochlear lip both appearing broken (see Figs 3-4). This damage no doubt affects the reported values for relative AP depth and relative articular width, with the AP depth being slightly 
underestimated and the articular width being slightly overestimated. However, it is highly unlikely that the damage is significant enough to affect our overall results, given that minor adjustments in either direction would still lead to UCMP 125868 being much closer in these two measures to the Papio/Lophocebus mean than to that of Cercocebus/Mandrillus. Functionally, the preserved humeral morphology of UCMP 125868 suggests that $P$. izodi was adapted to a more generalized semiterrestrial/terrestrial locomotor mode, as evidenced by a very posteriorly directed medial epicondyle and the lack of morphological specializations for manual foraging (Fig. 11). Among extant Papio and Lophocebus taxa, this morphology is more consistent with terrestrial baboons than with arboreal crested mangabeys, perhaps indicating that Lophocebus is secondarily derived in its arboreal mode of locomotion.

In sum, the evidence provided by UCMP 56693, assigned to Pr. antiquus, and UCMP 125868, assigned to P. izodi, supports the divergence of the major extant African papionin clades in the South African fossil record at Taung, dated to at least 3 to $2 \mathrm{Ma}$ (for estimated age of Taung, see Delson, 1984, 1988; McKee, 1993; McKee et al., 1995; Herries et al., 2013; Hopley et al., 2013). UCMP 56693 presents additional compelling evidence that the Cercocebus/Mandrillus clade once extended its range as far south as South Africa and confirms Pr. antiquus as an early member of this group (see also Gilbert, 2007, 2013; DeVreese and Gilbert, 2015). While it is still unclear whether $P$. izodi is a member of the modern genus Papio on the basis of its craniodental morphology (as argued, e.g., by Freedman 1957 et seq. and Szalay and Delson, 1979), the evidence presented by UCMP 125868 suggests that it may be a member of the Papio/Lophocebus clade rather than a stem African papionin (as proposed by Gilbert, 2013). Future 
phylogenetic analyses including both cranial and postcranial characters may ultimately help clarify its taxonomic status.

Unfortunately, as noted above, there are very few securely identified postcrania among stem African papionin taxa such as Parapapio and Pliopapio to help elucidate locomotor behavior polarity during papioninan evolution. Postcrania attributable to Parapapio jonesi from Hadar suggest that this taxon was more arboreal than living papioninans, with the exception of Lophocebus (Frost and Delson, 2002). Other postcrania from South Africa less securely attributable to any particular Parapapio taxon suggest both arboreal and (semi-)terrestrial locomotor behaviors and indicate locomotor diversity among stem African papionin taxa (e.g., Elton, 2001; Gommery et al., 2009, 2014). While postcrania attributed to Victoriapithecus and Parapapio lothagamensis both suggest that a semi-terrestrial locomotor adaptation is the most likely primitive condition for papionins as a group (Harrison, 1989; Leakey et al., 2003; Gilbert et al., 2010), a more complete understanding of papionin locomotor evolution is lacking. In the future, associated postcrania from stem African papionins such as Parapapio ado, Parapapio broomi, Parapapio whitei and Pliopapio alemui will be crucial in further determining character state polarities in papionin locomotor evolution. Given the postcranial specimens from Hadar attributed $P p$. jonesi, it may be possible in the future to make more detailed comparisons with South African postcranial specimens where Pp. jonesi and other species occur. For example, Elton (2001) suggested that a number of arboreal postcranial specimens at Sterkfontein and Bolt's Farm might be attributable to Pp. broomi; if some of these specimens at Sterkfontein, in particular, can be shown to share specific characters with $P p$. jonesi from Hadar, it may be possible to attribute these 21 
postcrania to Pp jonesi instead and, in turn, help narrow down the possibilities for attributing the remaining postcrania to other taxa.

For now, our approach has shown that isolated fossil postcrania can be taxonomically identified with a high degree of certainty in paleontological situations where 1) the number of likely referent species is limited and/or 2) the taxa in question are phylogenetically secure, with phylogenetically informative postcranial features documented within immediately inclusive taxa or broader clades. The combination of statistical analysis of metrical variables and cladistic analysis of qualitative features, each with taxonomic and/or functional value, produced strong concordant indications as to which fossil species the two Taung partial humeri belonged. In turn, these identifications shed light on the locomotor adaptations of the species Pr. antiquus and P. izodi, as well as on the paleozoogeography and locomotor evolution of their broader extant/fossil clades. We hope that future analyses in similar cases will be able to shed further light on papionin and, more broadly, primate locomotor evolution.

\section{Acknowledgements}

We thank Eileen Westwig (AMNH), Darrin Lunde, Nicole Edmison (USNM), Judith Chupasko, and Mark Omura (MCZ) for access to specimens under their care. The L.S.B. Leakey Foundation, Wenner-Gren Foundation, PSC-CUNY faculty research award program, Hunter College, and NSF DGE-0966166 (NYCEP IGERT award) provided

partial funding for this study. The late Professor Donald E. Savage (UCMP) arranged to loan ED much of the Taung collection for preparation and study in New York; Dr. Pat Holroyd and Dr. Leslea Hlusko facilitated study of the fossils in Berkeley by CCG. We 
thank JHE Editor Sarah Elton, an anonymous Associate Editor, and three anonymous reviewers for comments and suggestions that significantly improved this manuscript. 


\section{References}

Barnicot, N.A., Hewett-Emmett, D., 1972. Red cell and serum proteins of Cercocebus, Presbytis, Colobus and certain other species. Folia Primatol. 17, 442-457.

Barnicot, N.A., Wade, P.T., 1970. Protein structure and the systematics of Old World monkeys. In: Napier, J.R., Napier, P.H. (Eds.), Old World Monkeys: Evolution, Systematics, and Behavior. Academic Press, New York, pp. 29-56.

Beard, K.C., Dagosto, M., Gebo, D.L., Godinot, M., 1988. Interrelationships among primate higher taxa. Nature 331, 712-714.

Burrell, A.S., Jolly, C.J., Tosi, A.J., Disotell, T.R., 2009. Mitochondrial evidence for the hybrid origin of the kipunji, Rungwecebus kipunji (Primates: Papionini). Mol. Phyl. Evol. 51: 340-348.

Ciochon, R.L., 1994. Evolution of the Cercopithecoid Forelimb: Phylogenetic and Functional Implications From Morphological Analyses. University of California Press, Berkeley.

Cooke, C., 2012. The feeding, ranging, and positional behavior of Cercocebus torquatus (the red-capped mangabey) in Sette Cama, Gabon: A phylogenetic perspective. Ph.D. Dissertation, Ohio State University.

Cronin, J.E., Sarich, V.M., 1976. Molecular evidence for dual origin of mangabeys among Old World monkeys. Nature 260, 700-702.

Dagosto, M., Gebo, D.L., Beard, K.C., 1999. Revision of the Wind River faunas, early Eocene of central Wyoming. Part 14. Postcranium of Shoshonius cooperi 
(Mammalia: Primates). Ann. Carnegie Mus. 68, 175-311.

Dart, R.A., 1925. Australopithecus africanus: The man-ape of South Africa. Nature 115, 195-199.

Davenport, T.R.B., Stanley, W.T., Sargis, E.J., De Luca, D.W., Mpunga, N.E., Machaga, S.J., Olson, L.E., 2006. A new genus of African monkey, Rungwecebus: morphology, ecology, and molecular phylogenetics. Science 312, 1378-1381.

Delson, E., 1984. Cercopithecid biochronology of the African Plio-Pleistocene: correlation among eastern and southern hominid-bearing localities. Cour. Forsch.Inst. Senckenberg. 69, 199-218.

Delson, E., 1988. Chronology of South African australopith site units. In: Grine, F.E. (Ed.), Evolutionary History of the "Robust" Australopithecines. Aldine de Gruyter, New York, pp. 317-324.

Delson, E., Dean, D., 1993. Are Papio baringensis R. Leakey, 1969, and P. quadratirostris Iwamoto, 1982, species of Papio or Theropithecus? In: Jablonski, N. (Ed.), Theropithecus: The Rise and Fall of a Primate Genus. Cambridge University Press, Cambridge, pp. 125-156.

DeVreese, L., Gilbert, C.C., 2015. Phylogenetic relationships within the CercocebusMandrillus clade as indicated by craniodental morphology: implications for evolutionary biogeography. Am. J. Phys. Anthropol. DOI: 10.1002/ajpa.22780

Disotell, T.R., 1994. Generic level relationships of the Papionini (Cercopithecoidea). Am. J. Phys. Anthropol. 94, 47-57. 
Disotell, T.R., 2000. Molecular systematics of the Cercopithecidae. In: Whitehead, P., Jolly, C.J. (Eds.), Old World Monkeys. Cambridge University Press, Cambridge, pp. 29-56.

Disotell, T.R., Honeycutt, R., Ruvolo, M., 1992. Mitochondrial DNA phylogeny of the Old-World monkey tribe Papionini. Mol. Biol. Evol. 9, 1-13.

Dunn, R.H., 2010. Additional postcranial remains of omomyid primates from the Uinta Formation, Utah and implications for the locomotor behavior of large-bodied omomyids. J. Hum. Evol. 58, 406-417.

Dunn, R.H., Sybalsky, J.M., Conroy, G.C., Rasmussen, D.T., 2006. Hindlimb adaptations in Ourayia and Chipetaia, relatively large-bodied omomyine primates from the middle Eocene of Utah. Am. J. Phys. Anthropol. 131, 303-310.

Eisenhart, W.L. 1974. The fossil cercopithecoids of Makapansgat and Sterkfontein. B. A. thesis, Harvard College.

Elton, S., 2001. Locomotor and habitat classification of cercopithecoid postcranial material from Sterkfontein Member 4, Bolt’s Farm and Swartkrans Members 1 and 2, South Africa. Palaeont. Afr. 37, 115-126.

Finstermeier, K., Zinner, D., Brameier, M., Meyer, M., Kreuz, E., Hofreiter, M., Roos, C., 2013. A mitogenomic phylogeny of living primates. PLoS ONE 8, e69504. doi:10.1371/journal.pone.0069504

Fleagle, J.G., McGraw, W.S., 1999. Skeletal and dental morphology supports diphyletic 26 
origin of baboons and mandrills. Proc. Natl. Acad. Sci. USA 96, 1157-1161.

Fleagle, J.G., McGraw, W.S., 2002. Skeletal and dental morphology of African papionins: Unmasking a cryptic clade. J. Hum. Evol. 42, 267-292.

Freedman, L., 1957. The fossil Cercopithecoidea of South Africa. Ann. Transvaal Mus. 23, 121-262.

Freedman, L., 1961. New cercopithecoid fossils, including a new species from Taung, Cape Province, South Africa. Ann. S. Afr. Mus. 46, 1-14.

Freedman, L., 1965. Fossil and subfossil primates from the limestone deposits at Taung, Bolt’s Farm, and Witkrans, South Africa. Palaeont. Afr. 9, 19-48.

Frost, S.R., Delson, E., 2002. Fossil Cercopithecidae from the Hadar Formation and surrounding areas of the Afar Depression, Ethiopia. J. Hum. Evol. 43, 687-748.

Gear, J.H.S., 1926. A preliminary account of the baboon remains from Taungs. S. Afr. J. Sci. 23, 731-747.

Gear, J.H.S., 1958. The fossil baboons from Taungs. S. Afr. J. Med. Sci. 23, 205-223.

Gebo, D.L., Dagosto, M., Beard, K.C., Qi, T., 2001. Middle Eocene tarsals from China: implications for haplorhine evoution. Am. J. Phys. Anthropol. 116, 83-107.

Gebo, D.L., Dagosto, M., Ni, X., Beard, K.C., 2012. Species diversity and postcranial anatomy of Eocene primates from Shanguang, China. Ev. Anthropol. 21, 224238.

Gilbert, C.C., 2007. Craniomandibular morphology supporting the diphyletic origin of 
mangabeys and a new genus of the Cercocebus/Mandrillus clade, Procercocebus. J. Hum. Evol. 53, 69-102.

Gilbert, C.C., 2013. Cladistic analysis of extant and fossil African papionins using craniodental data. J. Hum. Evol. 64, 399-433.

Gilbert, C.C., Rossie, J.B., 2007. Congruence of molecules and morphology using a narrow allometric approach. Proc. Natl. Acad. Sci. USA 104, 11910-11914.

Gilbert, C.C., Frost, S.R., Strait, D.S., 2009. Allometry, sexual dimorphism, and phylogeny: A cladistic analysis of extant African papionins using craniodental data. J. Hum. Evol. 57, 298-320.

Gilbert, C.C., Goble, E.D., Hill, A., 2010. Miocene Cercopithecoidea from the Tugen Hills, Kenya. J. Hum. Evol. 59, 465-483.

Gilbert, C.C., Stanley, W.T., Olson, L.E., Davenport, T.R.B., Sargis, E.J., 2011. Morphological systematics of the kipunji (Rungwecebus kipunji) and the ontogenetic development of phylogenetically informative characters in the Papionini. J. Hum. Evol. 60, 731-745.

Gilbert, C.C., Frost, S.R., Delson, E., 2013. Appearance of the modern baboon, Papio hamadryas, in the Plio-Pleistocene fossil record: Evidence from South Africa. Am. J. Phys. Anthropol. 56S, 129.

Gilbert, C.C., Steininger, C.M., Kibii, J.M., Berger, L.R., 2015. Papio cranium from the hominin-bearing site of Malapa: implications for the evolution of modern baboon 
cranial morphology and South African Plio-Pleistocene biochronology. PLoS

ONE 10, e0133361. doi:10.1371/journal.pone.0133361

Gommery, D. Thackery, J.F., Senegas, F., Potze, S., Kgasi, L., 2009. Additional fossils of Parapapio sp. from Waypoint 160 (Bolt's Farm, South Africa), dated between 4 and 4.5 million years ago. Ann. Transvaal Mus. 46, 63-72.

Gommery, D., Senegas, F., Potze, S., Kgasi, L., Thackeray, J.F., 2014. Cercopithecoidea material from the Middle Pliocene site, Waypoint160, Bolt's Farm, South Africa. Ann. Ditsong Natl. Mus. Nat. Hist. 4, 1-8.

Gordon, A.D., Wood, B., 2013. Evaluating the use of pairwise dissimilarity metrics in paleoanthropology. J. Hum. Evol. 65, 465-77.

Guevara, E.E., Steiper, M.E., 2014. Molecular phylogenetic analysis of the Papionina using concatenation and species tree methods. J. Hum. Evol. 66, 18-28.

Harris, E.E., 2000. Molecular systematics of the Old World monkey tribe Papionini: analysis of the total available genetic sequences. J. Hum. Evol. 38, 235-256.

Harris, E.E., Disotell, T.R., 1998. Nuclear gene trees and the phylogenetic relationships of the mangabeys (Primates: Papionini). Mol. Biol. Evol. 15, 892 - 900.

Harrison, T., 1989. New postcranial remains of Victoriapithecus from the middle Miocene of Kenya. J. Hum. Evol. 18, 3-54.

Haughton, S.H., 1925. Demonstration (of Taung fossils). Trans. Roy. Soc. S. Afr. 12, lxviii.

Herries, A.I.R., Pickering, R., Adams, J.W., Curnoe, D., Warr, G., Latham, A.G., Shaw, 29 
J., 2013. A multi-disciplinary perspective on the age of Australopithecus in Southern Africa. In: Reed, K.E., Fleagle, J.G., Leakey, R.E. (Eds.), The Paleobiology of Australopithecus. Springer, Dordrecht, pp. 21-40.

Hewett-Emmett, D., Cook, C.N., Barnicot, M.A., 1976. Old World monkey hemoglobins: Deciphering phylogeny from complex patterns of molecular evolution. In: Goodman, M., Tashian, R.E., Tashian, J.H. (Eds.), Molecular Anthropology: Genes and Proteins in the Evolutionary Ascent of the Primates. Plenum Press, New York, pp. 257-275.

Hopley, P.J., Herries, A.I.R., Baker, S.E., Kuhn, B.F., Menter, C.G., 2013. Brief communication: beyond the South African cave paradigm- Australopithecus africanus from Plio-Pleistocene paleosol deposits at Taung. Am. J. Phys. Anthropol. 151, 316-324.

Jablonski, N., 2002. Fossil Old World monkeys: the late Neogene radiation. In: Hartwig, W. (Ed.), The Primate Fossil Record. Cambridge University Press, Cambridge, pp. 255-299.

Jablonski, N., Frost, S.R., 2010. Cercopithecoidea. In: Werdelin, L., Sanders, W.J. (Eds.), Cenozoic Mammals of Africa. University of California Press, Berkeley, pp. 393428.

Jungers, W.L., Falsetti, A.B., Wall, C.E., 1995. Shape, relative size, and sizeadjustments in morphometrics. Yearb. Phys. Anthropol. 38, 137-161.

Klecka, W., 1980. Discriminant analysis. Sage Publications, Beverly Hills Calif. 
Lachenbruch, P., 1975. Discriminant Analysis. Hafner Press, New York.

Leakey, M.G., Teaford, M.F., Ward, C.V., 2003. Cercopithecidae from Lothagam. In: Leakey, M.G., Harris, J.M. (Eds.), Lothagam: The Dawn of Humanity in Eastern Africa. Columbia University Press, New York, pp. 201-248.

Liedigk, R., Roos, C., Brameier, M., Zinner, D., 2014. Mitogenomics of the Old World monkey tribe Papionini. BMC Evol. Biol. 14, 176.

McKee, J.K., 1993. Faunal dating of the Taung hominid fossil deposit. J. Hum. Evol. 25, 363-376.

McKee, J.K., Thackeray, J.F., Berger, L.R., 1995. Faunal assemblage seriation of Southern African Pliocene and Pleistocene fossil deposits. Am. J. Phys. Anthropol. 96, 235-250.

Nakatsukasa, M., 1994a. Intrageneric variation of limb bones and implications for positional behavior in Old World monkeys. Z. Morphol. Anthropol. 80, 125-136.

Nakatsukasa, M., 1994b. Morphology of the humerus and femur in African mangabeys and guenons: Functional adaptation and implications for the evolution of positional behavior. Afr. Stud. Monographs. 21, 1-61.

Nakatsukasa, M., 1996. Locomotor differentiation and different skeletal morphologies in mangabeys (Lophocebus and Cercocebus). Folia Primatol. 66, 15-24.

Olson, L.E., Sargis, E.J., Stanley, W.T., Hildebrandt, K.B.P., Davenport, T.R.B., 2008. 
Additional molecular evidence strongly supports the distinction between the recently described African primate Rungwecebus kipunji (Cercopithecidae, Papionini) and Lophocebus. Mol. Phylogenet. Evol. 48, 789-794.

Peabody, F.E., 1954. Travertines and cave deposits of the Kaap escarpment of South Africa, and the type locality of Australopithecus africanus. Bull. Geol. Soc. Am. 65, 671-706.

Perelman, P., Johnson, W.E., Roos, C., Seuánez, H.N., Horvath, J.E., Moreira, M.A.M., Kessing, B., Pontius, J., Roelke, M., Rumpler, Y., Schneider, M.P.C., Silva, A., O'Brien, S.J., Pecon-Slattery, J., 2011. A molecular phylogeny of living primates. PLoS Genet. 7, e1001342. doi:10.1371/journal.pgen.1001342

Pozzi, L., Hodgson, J.A., Burrell, A.S., Sterner, K.N., Raaum, R.L., Disotell, T.R., 2014. Primate phylogenetic relationships and divergence dates inferred from complete mitochondrial genomes. Mol. Phylogenet. Evol. 75, 165-183.

Roberts, T., Davenport, T.R.B., Hildebrandt, K.B.P., Jones, T., Stanley, W.T., Sargis, E.J., Olson, L.E., 2010. The biogeography of introgression in the critically endangered African monkey Rungwecebus kipunji. Biol. Letters 6, 233-237.

Rose, K.D., Rana, R.S., Sahni, A., Kumar, K., Missiaen, P., Singh, L., Smith, T., 2009. Early Eocene primates from Gujarat, India. J. Hum. Evol. 56, 366-404.

Springer, M.S., Meredith, R.W., Gatesy, J., Emerling, C.A., Park, J., Rabosky, D.L., Stadler, T., Steiner, C., Ryder, O.A., Janecka, J.E., Fisher, C.A., Murphy, W.J., 2012. Macroevolutionary dynamics and historical biogeography of primate diversification inferred from a species supermatrix. PLoS ONE 7, e49521. doi:10.1371/journal.pone.0049521 
Strasser, E., Delson, E., 1987. Cladistic analysis of cercopithecid relationships. J. Hum. Evol. 16, 81-99.

Swofford, D.L., 2003. PAUP*. Phylogenetic Analysis Using Parsimony (*and Other Methods). Version 4.10b. Sinauer Associates, Sunderland, Massachusetts.

Szalay, F., Delson, E., 1979. Evolutionary History of the Primates. Academic Press, New York.

Tabachnick, B.G., Fidell, L.A., 1996. Using Multivariate Statistics. HarperCollins College Publishers, New York.

Tosi, A.J., Morales, J.C., Melnick, D.J., 2000. Comparison of Y chromosome and mtDNA phylogenies leads to unique inferences of macaque evolutionary history. Mol. Phylogenet. Evol. 17, 133-144.

Tosi, A.J., Disotell, T.R., Carlos Morales, J., Melnick, D.J., 2003. Cercopithecine Ychromosome data provide a test of competing morphological evolutionary hypotheses. Mol. Phylogenet. Evol. 27, 510-521.

Xing, J., Wang, H., Han, K., Ray, D.A., Huang, C.H., Chemnick, L.G., Stewart, C-B., Disotell, T.R., Ryder, O.A., Batzer, M.A., 2005. A mobile element based phylogeny of Old World monkeys. Mol. Phylogenet. Evol. 37, 872-880.

Zinner, D., Arnold, M.L., Roos, C., 2009. Is the new primate genus Rungwecebus a baboon? PLoS ONE 4, e4859. doi:10.1371/journal.pone.0004859 


\section{Figure Captions}

Figure 1. Hypothesized phylogeny of the African papionins combining results from previous morphological (Gilbert and Rossie, 2007; Gilbert et al., 2009, 2011) and molecular studies (Disotell et al., 1992; Disotell, 1994, 2000; Harris and Disotell, 1998; Harris, 2000; Tosi et al., 2003; Davenport et al., 2006; Olson et al., 2008; Burrell et al., 2009; Zinner et al., 2009; Roberts et al., 2010). Drawings courtesy of Stephen Nash.

Figure 2. Illustrations of quantitative measurements collected during this study. $1=$ Deltoid plane width, 2 = Supinator crest length, 3 = Articular width, $4=$ Biepicondylar width, $5=$ Brachialis flange width, $6=$ anteroposterior (AP) depth at midshaft, $7=$ Distal AP depth, 8 = Olecranon fossa width. See Table 2 for complete descriptions.

Figure 3. Papionin humeri in anterior view. From left to right, $P$. anubis male (AMNH 82097), P. anubis female (AMNH 216247), presumed female UCMP 125868, presumed male UCMP 56693, C. agilis male (AMNH 81250), M. sphinx male (AMNH 170364). Note the expanded deltoid plane, broad brachialis flange and extended supinator crest, and prominent medial trochlear lip (all marked by white arrows) exhibited by M. sphinx, C. agilis, and UCMP 56693.

Figure 4. Papionin humeri in posterior view. From left to right, $P$. anubis male (AMNH 82097), P. anubis female (AMNH 216247), presumed female UCMP 125868, presumed male UCMP 56693, C. agilis male (AMNH 81250), M. sphinx male (AMNH 
170364). Note the expanded deltoid plane and the narrow and deep olecranon fossa (both marked by white arrows) exhibited by M. sphinx, C. agilis, and UCMP 55693.

Figure 5. Boxplots comparing male papionin humeral shape indices. $C / M=$ Cercocebus/Mandrillus, $56693=$ UCMP 56693, P/L = Papio/Lophocebus, $125868=$ UCMP 125868, Mc = Macaca. See also Figs. 6 and 7 for female and pooled sex data and Table 5 for breakdown by species.

Figure 6. Boxplots comparing female papionin humeral shape indices. $C / M=$ Cercocebus/Mandrillus, 56693 = UCMP 56693, P/L = Papio/Lophocebus, $125868=$ UCMP 125868, Mc = Macaca. See also Figs. 5 and 7 for male and pooled sex data and Table 5 for breakdown by species.

Figure 7. Boxplots comparing pooled-sex papionin humeral shape indices. $C / M=$ Cercocebus/Mandrillus, 56693 = UCMP 56693, P/L = Papio/Lophocebus, $125868=$ UCMP 125868, Mc = Macaca. See also Figs. 5 and 6 for male and female data and Table 5 for breakdown by species. 
Figure 8. Results of DFA with minimum convex polygons around the data points for each major group. a) quantitative DFA excluding macaques, b) quantitative plus qualitative DFA excluding macaques, c) quantitative DFA including macaques, d) quantitative plus qualitative DFA including macaques. $C / M=$ Cercocebus/Mandrillus, $56693=$ UCMP 56693, P/L = Papio/Lophocebus, $125868=$ UCMP 125868, Mc $=$ Macaca.

Figure 9. Results from DFA by genus. a) quantitative DFA excluding macaques, b) quantitative plus qualitative DFA excluding macaques, c) quantitative DFA including macaques, d) quantitative plus qualitative DFA including macaques. $C=$ Cercocebus, $M$ $=$ Mandrillus, $56693=$ UCMP 56693, $P=$ Papio, $L=$ Lophocebus, $125868=$ UCMP 125868, Mc = Macaca .

Figure 10. Strict and majority rule consensus of the three most parsimonious trees (MPTs) resulting from a cladistic analysis of 24 humeral characters (including two body size characters). Numbers above branches represent bootstrap support values. Numbers in parentheses below branches represent decay indices. Length $=57$ steps, consistency index $(\mathrm{CI})=0.684$, homoplasy index $(\mathrm{HI})=0.316$, retention index $(\mathrm{RI})=0.654$, rescaled 
retention index $(\mathrm{RC})=0.447$. For matrix and individual MPTs, please see SOM.

Figure 11. UCMP 125868 and UCMP 56693 in distal view. Note the posterior orientation of the medial epicondyle (marked by white arrows) in both specimens.

Photos not to scale. 


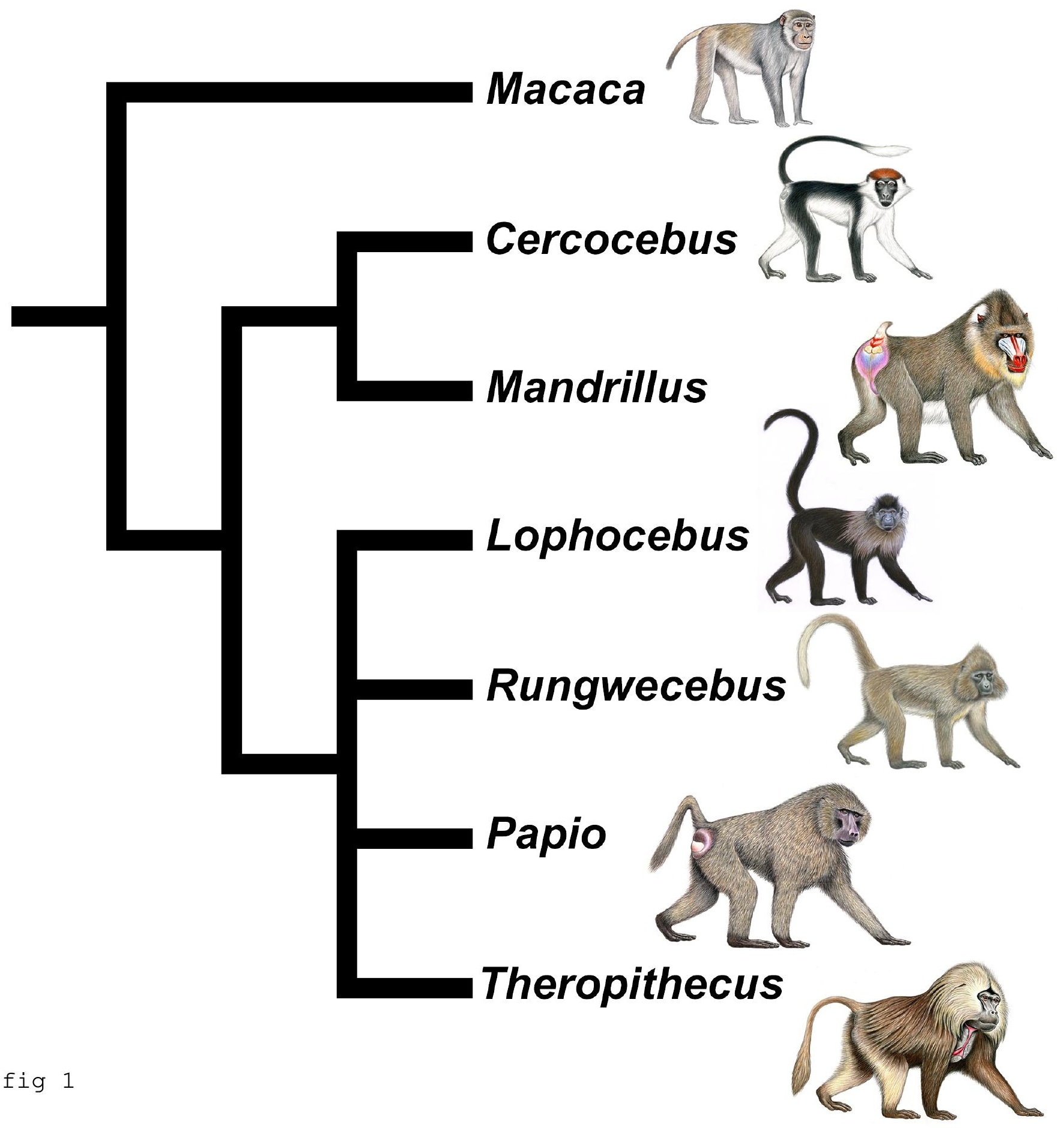


fig 2
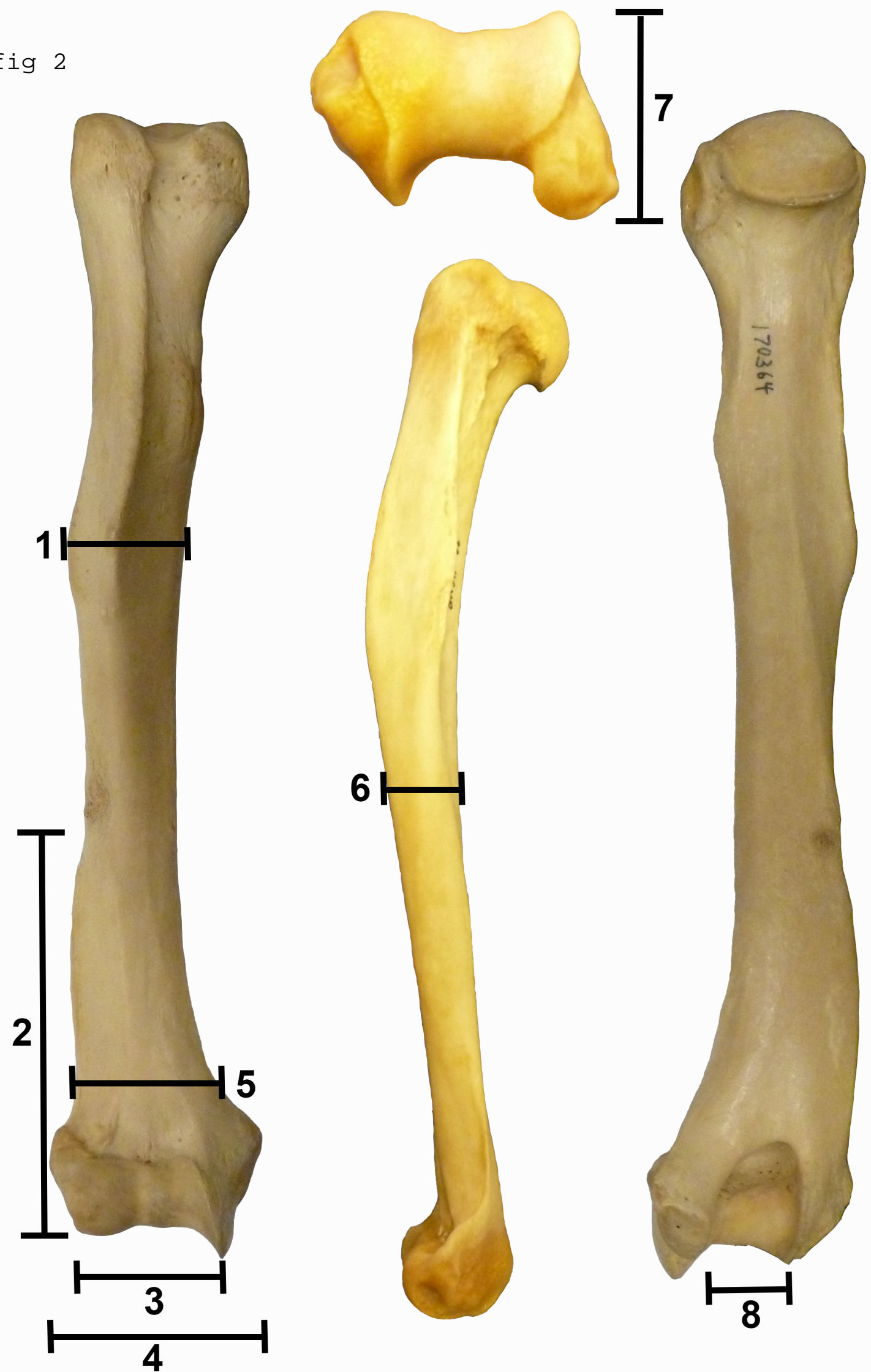



$$
\iint_{1} \mid
$$


Table 1. Sample used in this study.

\begin{tabular}{ll}
\hline Species & Sample size $\left(\mathrm{F}, \mathrm{M}^{\mathrm{a}}\right)$ \\
\hline Mandrillus sphinx & \\
Mandrillus leucophaeus & $n=8(3 \mathrm{~F}, 5 \mathrm{M})$ \\
Cercocebus agilis & $n=3(3 \mathrm{M})$ \\
Cercocebus torquatus & $n=2(2 \mathrm{M})$ \\
Lophocebus albigena & $n=10(4 \mathrm{~F}, 6 \mathrm{M})$ \\
Lophocebus aterrimus & $n=3(3 \mathrm{M})$ \\
Papio anubis & $n=15(6 \mathrm{~F}, 9 \mathrm{M})$ \\
Papio ursinus & $n=3(2 \mathrm{~F}, 1 \mathrm{M})$ \\
Papio cynocephalus & $n=3(2 \mathrm{~F}, 1 \mathrm{M})$ \\
Macaca fascicularis & $n=4(2 \mathrm{~F}, 2 \mathrm{M})$ \\
Macaca nemestrina & $n=5(1 \mathrm{~F}, 4 \mathrm{M})$ \\
Taung Fossil- UCMP 125868 & $n=1(\mathrm{~F} ?)$ \\
Taung Fossil- UCMP 56693 & $n=1(\mathrm{M} ?)$ \\
\hline
\end{tabular}

a $\mathrm{F}=$ Female, $\mathrm{M}=$ Male. 
Table 2. Quantitative measurements and their definitions ${ }^{\mathrm{a}}$.

Measurement

AP Depth at Midshaft

Biepicondylar Width

Articular Width

Olecranon Fossa Width

Distal AP Depth

Deltoid Plane Width

Supinator Crest Length

Brachialis Flange Width

Geometric Mean

\section{Definition}

Maximum anterior-posterior depth of the humerus measured approximately at midshaft in anterior view

Maximum medial-lateral width across the medial and lateral epicondyles in anterior view

Maximum medial-lateral width across the distal articular surface (trochlea + capitulum) in anterior view

Maximum medial-lateral width across the olecranon fossa, measured at the base of the fossa, in posterior view

Maximum anterior-posterior depth of the distal articular surface, including epicondyles, in distal view

Maximum medial-lateral width across the deltoid plane at whatever level it occurs in anterior view

Maximum length of the supinator crest taken as the maximum distance from the lateral distal articulation to the approximate level where the brachioradialis/supinator crest meets the humeral shaft in anterior view Maximum width of the brachialis flange taken as the maximum width of the humerus at the level where the medial epicondyle meets the shaft in anterior view Geometric mean calculated from the eight quantitative measurements listed above

a See Figure 2 for illustrations of measurements. 
Table 3. Qualitative characters with character state definitions.

\begin{tabular}{|c|c|c|}
\hline Character & Character States & Reference \\
\hline Supinator crest extension & $\begin{array}{l}1=\text { does not extend proximally } \\
2=\text { extends proximally }\end{array}$ & Fleagle and McGraw, 2002 \\
\hline $\begin{array}{l}\text { Height of the lateral wall of the olecranon } \\
\text { fossa }\end{array}$ & $\begin{array}{l}1=\text { short or moderate height for a } \\
\text { papionin } \\
2=\text { tall for a papionin }\end{array}$ & Fleagle and McGraw, 2002 \\
\hline Depth of the olecranon fossa & $\begin{array}{l}1=\text { shallow or average depth for } \\
\text { a papionin } \\
2=\text { deep for a papionin }\end{array}$ & this study \\
\hline Shape of the olecranon fossa & $\begin{array}{l}1=\text { rounded or an overall } \\
\text { gentle/broad arch-shape across } \\
\text { the superior margin } \\
2=\text { triangular or an overall } \\
\text { narrow U-shape across the } \\
\text { superior margin coming to a } \\
\text { more distinct superior point than } \\
\text { the rounded state }\end{array}$ & this study \\
\hline
\end{tabular}


Table 4. Qualitative characters with character state definitions. ${ }^{a}$

\begin{tabular}{|c|c|c|c|c|}
\hline Character & Definition & Character States & $\begin{array}{c}\text { Character } \\
\text { Type }\end{array}$ & Reference \\
\hline H1 & $\begin{array}{c}\text { Relative Deltoid Plane Width } \\
\text { (maximum width across the deltoid } \\
\text { plane/geometric mean) }\end{array}$ & $\begin{array}{c}0 \text { = relatively narrow deltoid plane } \\
1 \text { = intermediate deltoid plane } \\
2=\text { relatively broad deltoid plane }\end{array}$ & Quantitative & $\begin{array}{c}\text { Fleagle and McGraw, 2002; } \\
\text { See also Table 5, Figure } 5\end{array}$ \\
\hline $\mathrm{H} 2$ & $\begin{array}{c}\text { Relative Brachialis Flange Width } \\
\text { (maximum width across the brachialis } \\
\text { flange/geometric mean) }\end{array}$ & $\begin{array}{l}0=\text { not expanded } \\
1=\text { intermediate } \\
2 \text { = expanded }\end{array}$ & Quantitative & $\begin{array}{c}\text { Fleagle and McGraw, 2002; } \\
\text { See also Table 5, Figure } 5\end{array}$ \\
\hline H3 & Supinator Crest Extension & $\begin{array}{c}0=\text { not extended proximally } \\
1=\text { polymorphic } \\
2=\text { extended proximally }\end{array}$ & Qualitative & $\begin{array}{c}\text { Fleagle and McGraw, 2002; } \\
\text { See also Tables } 3 \text { and 5; } \\
\text { Figure } 5\end{array}$ \\
\hline $\mathrm{H} 4$ & $\begin{array}{l}\text { Relative Distal Articular Breadth } \\
\text { (maximum width across the distal articular } \\
\text { surface/geometric mean) }\end{array}$ & $\begin{array}{c}0 \text { = relatively narrow articulation } \\
1 \text { = intermediate articulation } \\
2 \text { = relatively broad articulation }\end{array}$ & Quantitative & $\begin{array}{c}\text { Fleagle and McGraw, 2002; } \\
\text { See also Table 5, Figure } 5\end{array}$ \\
\hline H5 & Medial Trochlear Lip Shape & $\begin{array}{c}0=\text { typical papionin } \\
1=\text { polymorphic } \\
2=\text { prominent/extended }\end{array}$ & Qualitative & Fleagle and McGraw, 2002 \\
\hline H6 & $\begin{array}{l}\text { Relative Olecranon Fossa Width } \\
\text { (maximum width of the olecranon } \\
\text { fossa/geometric mean) }\end{array}$ & $\begin{array}{c}0=\text { relatively narrow olecranon fossa } \\
1=\text { intermediate olecranon fossa } \\
2=\text { relatively broad olecranon fossa }\end{array}$ & Quantitative & $\begin{array}{c}\text { Fleagle and McGraw, 2002; } \\
\text { See also Table 5, Figure } 6\end{array}$ \\
\hline H7 & Height of the Olecranon Fossa Lateral Wall & $\begin{array}{c}0=\text { short } / \text { moderate } \\
1=\text { prominent } / \text { tall }\end{array}$ & Qualitative & $\begin{array}{l}\text { Fleagle and McGraw, 2002; } \\
\text { See also Tables } 3 \text { and } 5\end{array}$ \\
\hline H8 & Depth of the Olecranon fossa & $\begin{array}{c}0=\text { shallow } / \text { moderate } \\
1=\text { polymorphic } \\
2=\text { deep }\end{array}$ & Qualitative & See also Tables 3 and 5 \\
\hline
\end{tabular}


Relative Distal AP Depth (maxiumum AP Depth of the distal articulation/geometric mean)

Medial Epicondyle Orientation (estimated in degrees, $0=$ horizontal $/$ medial and $90=$ perpendicular/posterior)

Body Size (geometric mean of eight humeral measurements; see Materials and Methods)

$$
0=\text { rounded }
$$$$
1 \text { = polymorphic }
$$$$
2 \text { = triangular }
$$

$0=$ relative shallow distal AP depth

$1=$ intermediate distal AP depth

2 = relatively deep distal AP depth

$0=0-45$ degrees

$1=45-60$ degrees

$2=>60$ degrees

$0=$ relatively small humerus

$1=$ relatively large humerus
Qualitative

See also Tables 3 and 5

Quantitative

Qualitative

Quantitative
Fleagle and McGraw, 2002; See also Tables 3 and 5

Harrison, 1989; Frost and Delson, 2002

This study

\footnotetext{
${ }^{a}$ All characters were considered ordered. For quantitative characters, gap-weighted coding was used (Thiele, 1993), employing two or three character states, as described above. Males and females were coded separately for each character, resulting in 24 total characters in the analysis. The full matrix is provided as a nexus file in the online supporting information accompanying this article.
} 
Table 5. Average relative quantitative and qualitative character values for each taxon.

\begin{tabular}{|c|c|c|c|c|c|c|c|c|c|c|c|c|}
\hline Species & $\begin{array}{c}\text { Sample size } \\
\text { by sex }\end{array}$ & GM & $\begin{array}{c}\text { Rel } \\
\text { Articular } \\
\text { Width }\end{array}$ & $\begin{array}{c}\text { Rel } \\
\text { OF } \\
\text { Width }\end{array}$ & $\begin{array}{c}\text { Rel } \\
\text { Distal } \\
\text { AP } \\
\text { Depth }\end{array}$ & $\begin{array}{c}\text { Rel } \\
\text { Deltoid } \\
\text { Width }\end{array}$ & $\begin{array}{c}\text { Rel } \\
\text { Supinator } \\
\text { Length }\end{array}$ & $\begin{array}{c}\text { Rel } \\
\text { Brachialis } \\
\text { Width }\end{array}$ & $\begin{array}{l}\text { Supinator } \\
\text { extension }\end{array}$ & $\begin{array}{c}\text { OF Lateral } \\
\text { Margin } \\
\text { Height }\end{array}$ & $\begin{array}{c}\text { OF } \\
\text { Depth }\end{array}$ & $\begin{array}{c}\text { OF } \\
\text { Shape }\end{array}$ \\
\hline \multirow{2}{*}{ Mandrillus sphinx } & \multirow{2}{*}{$\begin{array}{c}\text { Females }(n=3) \\
\text { Males }(n=5)\end{array}$} & 22.02 & 1.08 & 0.58 & 0.86 & 0.69 & 2.89 & 1.06 & 2.00 & 1.33 & 1.67 & 1.00 \\
\hline & & 31.30 & 1.06 & 0.54 & 0.88 & 0.73 & 2.76 & 1.13 & 2.00 & 1.80 & 2.00 & 2.00 \\
\hline Mandrillus leucophaeus & Males $(n=2)$ & 28.87 & 1.11 & 0.58 & 0.85 & 0.63 & 2.68 & 1.09 & 2.00 & 1.00 & 2.00 & 1.50 \\
\hline Cercocebus agilis & Males $(n=3)$ & 20.63 & 1.01 & 0.57 & 0.90 & 0.73 & 2.78 & 1.03 & 2.00 & 2.00 & 2.00 & 2.00 \\
\hline Cercocebus torquatus & Males $(n=2)$ & 21.73 & 1.03 & 0.58 & 0.86 & 0.73 & 2.76 & 1.07 & 2.00 & 1.50 & 1.50 & 1.00 \\
\hline \multirow{3}{*}{ Cercocebus/Mandrillus } & \multirow{3}{*}{$\begin{array}{c}\text { Pooled Sex }(n=15) \\
\text { Females }(n=3) \\
\text { Males }(n=12)\end{array}$} & 25.71 & $1.06^{*}$ & $0.56 *$ & 0.87 & $0.71^{*}$ & 2.78 & $1.08 *$ & $2.00 * *$ & $1.60 * *$ & $1.87^{* *}$ & $1.60^{* *}$ \\
\hline & & 22.02 & 1.08 & $0.58 *$ & 0.86 & 0.69 & 2.89 & 1.06 & $2.00^{* *}$ & 1.33 & 1.67 & 1.00 \\
\hline & & 26.63 & $1.05^{*}$ & $0.56 *$ & 0.88 & $0.71^{*}$ & 2.75 & $1.09 *$ & $2.00 * *$ & $1.67 * *$ & $1.92 * *$ & $1.75^{* *}$ \\
\hline \multirow{2}{*}{ Lophocebus albigena } & \multirow{2}{*}{$\begin{array}{c}\text { Females }(n=4) \\
\text { Males }(n=6)\end{array}$} & 15.77 & 1.12 & 0.67 & 0.86 & 0.67 & 2.64 & 1.01 & 1.00 & 1.00 & 1.25 & 1.25 \\
\hline & & 18.60 & 1.09 & 0.67 & 0.87 & 0.64 & 2.65 & 1.04 & 1.00 & 1.00 & 1.00 & 1.17 \\
\hline Lophocebus aterrimus & Males ( $\mathrm{n}=3)$ & 19.52 & 1.10 & 0.64 & 0.83 & 0.66 & 2.89 & 1.03 & 1.00 & 1.00 & 1.00 & 1.00 \\
\hline \multirow{2}{*}{ Papio anubis } & \multirow{2}{*}{$\begin{array}{c}\text { Females }(n=7) \\
\text { Males }(n=8)\end{array}$} & 23.82 & 1.12 & 0.61 & 0.93 & 0.64 & 2.72 & 1.01 & 1.00 & 1.00 & 1.14 & 1.14 \\
\hline & & 28.65 & 1.11 & 0.63 & 0.93 & 0.64 & 2.66 & 0.98 & 1.25 & 1.13 & 1.13 & 1.00 \\
\hline \multirow{2}{*}{ Papio ursinus } & \multirow{2}{*}{$\begin{array}{c}\text { Females }(n=2) \\
\text { Males }(n=1)\end{array}$} & 23.29 & 1.06 & 0.63 & 0.95 & 0.58 & 2.89 & 1.05 & 1.00 & 1.00 & 1.00 & 1.00 \\
\hline & & 28.74 & 1.09 & 0.63 & 0.92 & 0.62 & 2.24 & 1.15 & 1.00 & 1.00 & 1.00 & 1.00 \\
\hline \multirow{2}{*}{ Papio cynocephalus } & \multirow{2}{*}{$\begin{array}{c}\text { Females }(n=2) \\
\text { Males }(n=1)\end{array}$} & 20.94 & 1.15 & 0.63 & 1.00 & 0.64 & 2.62 & 0.94 & 1.00 & 1.00 & 1.50 & 1.00 \\
\hline & & 25.31 & 1.16 & 0.66 & 0.93 & 0.61 & 2.94 & 0.90 & 1.00 & 1.00 & 1.00 & 1.00 \\
\hline \multirow{3}{*}{ Papio/Lophocebus } & \multirow{3}{*}{$\begin{array}{l}\text { Pooled Sex }(n=34) \\
\text { Females }(n=15) \\
\text { Males }(n=19)\end{array}$} & 22.70 & $1.11^{*}$ & $0.64 *$ & 0.91 & $0.64 *$ & 2.70 & $1.01^{*}$ & $1.06^{* *}$ & $1.03^{* *}$ & $1.12^{* *}$ & $1.09 * *$ \\
\hline & & 21.22 & 1.11 & $0.63^{*}$ & 0.92 & 0.64 & 2.71 & 1.01 & $1.00 * *$ & 1.00 & 1.20 & 1.13 \\
\hline & & 23.86 & $1.10^{*}$ & $0.64 *$ & 0.89 & $0.64 *$ & 2.68 & $1.01^{*}$ & $1.11^{* *}$ & $1.05^{* *}$ & $1.05^{* *}$ & $1.05^{* *}$ \\
\hline \multirow{3}{*}{ Macaca sp. } & \multirow{3}{*}{$\begin{array}{c}\text { Pooled Sex }(n=9) \\
\text { Females }(n=3) \\
\text { Males }(n=6)\end{array}$} & 19.30 & 1.07 & $0.58^{*}$ & 0.88 & 0.68 & 2.86 & 1.06 & $1.56^{* *}$ & $1.56^{* *}$ & $1.56^{* *}$ & $1.78^{* *}$ \\
\hline & & 14.25 & 1.10 & 0.61 & 0.89 & 0.62 & $3.09 *$ & 1.03 & 1.33 & 1.33 & 1.33 & $2.00^{* *}$ \\
\hline & & 21.85 & 1.06 & $0.56^{*}$ & 0.87 & 0.71 & 2.74 & 1.07 & $1.67 * *$ & $1.67 * *$ & $1.67^{* *}$ & $1.67 * *$ \\
\hline
\end{tabular}




\begin{tabular}{|c|c|c|c|c|c|c|c|c|c|c|c|c|}
\hline UCMP 125868 & Female? $(\mathrm{n}=1)$ & 21.96 & 1.13 & 0.65 & 0.96 & 0.67 & 1.97 & 1.15 & 1.00 & 1.00 & 1.00 & 1.00 \\
\hline UCMP 56693 & Male? $(\mathrm{n}=1)$ & 26.07 & 0.97 & 0.53 & 0.94 & 0.76 & 2.57 & 1.04 & 2.00 & 1.00 & 2.00 & 2.00 \\
\hline
\end{tabular}

a GM= Geometric Mean, Rel = Relative, OF = Olecranon Fossa, AP = Anterior-Posterior, For definitions of measurements, see Table 2. * indicates those values that are significant at the $p<$ 0.05 level between the Cercocebus/Mandrillus and Papio/Lophocebus groups and the Macaca and Papio/Lophocebus groups as determined by ANOVAs and t-tests. ** indicates those values that are significant at the $p<0.05$ level between the Cercocebus/Mandrillus and Papio/Lophocebus groups and the Macaca and Papio/Lophocebus groups as determined by Mann-Whitney Utests. Note that there are no significant differences between the Cercocebus/Mandrillus and Macaca groups in these analyses. 
Table 6. Correlation coeffecients and classification statistics in DFA analyses. ${ }^{a}$

\begin{tabular}{|c|c|c|c|c|}
\hline Analysis & Function 1 & Function 2 & Fossil Classification & $\begin{array}{c}\text { Figure } \\
\text { Reference }\end{array}$ \\
\hline $\begin{array}{c}\text { DFA 1: By clade, } \\
\text { quantitative, no Macaca } \\
\text { 93.9\% Correctly Classified } \\
\text { 91.8\% Cross-validation }\end{array}$ & $\begin{array}{c}\text { Relative Olecranon Fossa Width } r=0.600 \\
\text { Relative Deltoid Width } r=-0.457 \\
\text { Relative Articular Width } r=0.402 \\
\text { Relative Brachialis Width } r=-0.387 \\
\text { Geometric Mean } r=-0.223\end{array}$ & N/A & $\begin{array}{l}56693=C / M(99.5 \%) \\
125868=P / L(99.9 \%)\end{array}$ & See Fig. 8a \\
\hline $\begin{array}{c}\text { DFA 2: By clade, } \\
\text { quantitative + qualitative, } \\
\text { no } \text { Macaca } \\
\text { 100\% Correctly Classified } \\
\text { 95.9\% Cross-validation }\end{array}$ & $\begin{array}{c}\text { Qualitative Supinator Extension } r=0.682 \\
\text { Olecranon Fossa Depth } r=0.325 \\
\text { Height of the Lateral Wall of the Olecranon } \\
\text { Fossa } r=0.265 \\
\text { Relative Olecranon Fossa Width } r=-0.248 \\
\text { Olecranon Fossa Shape } r=0.202 \\
\text { Relative Deltoid Width } r=0.189 \\
\text { Relative Articular Width } r=-0.166 \\
\text { Relative Brachialis Width } r=0.160\end{array}$ & N/A & $\begin{array}{l}56693=C / M(100 \%) \\
125868=P / L(100 \%)\end{array}$ & See Fig. $8 b$ \\
\hline $\begin{array}{c}\text { DFA 3: By clade, } \\
\text { quantitative, with } \text { Macaca } \\
\text { 87.9\% Correctly Classified } \\
\text { 74.1\% Cross-validation }\end{array}$ & $\begin{array}{c}\text { Relative Olecranon Fossa Width } r=0.599 \\
\text { Relative Deltoid Width } r=-0.379 \\
\text { Relative Articular Width } r=0.379 \\
\text { Relative Brachialis Width } r=-0.372 \\
\text { Relative AP-Depth } r=0.228\end{array}$ & $\begin{array}{c}\text { Geometric Mean } r=0.876 \\
\text { Relative Supinator Length } r=-0.274\end{array}$ & $\begin{array}{l}56693=C / M(74.8 \%) \\
125868=P / L(99.9 \%)\end{array}$ & See Fig. 8c \\
\hline
\end{tabular}


Qualitative Supinator Extension $r=0589$

Olecranon Fossa Depth $r=0.354$

DFA 4: By clade, quantitative + qualitative, with Macaca

91.4\% Correctly Classified 82.8\% Cross-validation

DFA 1: By clade, quantitative, no Macaca 93.9\% Correctly Classified 85.7\% Cross-validation

DFA 6: By genus, quantitative + qualitative, no Macaca 98\% Correctly Classified 89.8\% Cross-validaion

DFA 7: By genus, quantitative, with Macaca 82.8\% Correctly Classified 75.9\% Cross-validation

DFA 8: By genus, quantitative + qualitative, with Macaca 93.1\% Correctly Classified 79.3\% Cross-validation
Geometric Mean $r=0.632$

Height of the Lateral Wall of the Olecranon

$$
\text { Fossa } r=0.312
$$

Relative Deltoid Width $r=0.203$

Relative Articular Width $r=-0.201$

Relative Brachialis Width $r=0.200$

$$
\text { Relative AP-Depth } r=-0.120
$$

\section{Geometric Mean $r=0.647$}

Qualitative Supinator Extension $r=0.633$

Olecranon Fossa Depth $r=0.297$

Relative Deltoid Width $r=0.200$

Olecranon Fossa Shape $r=0.198$

Relative Supinator Length $r=0.057$

Geometric Mean $r=0.543$

Relative AP Depth $r=0.448$

Qualitative Supinator Extension $r=-0.476$

Olecranon Fossa Depth $r=-0.285$
Olecranon Fossa Shape $r=-0.421$

Relative Supinator Length $r=-0.254$

Relative Olecranon Fossa Width $r=0.677$

Relative Deltoid Width $r=-0.456$

Relative Brachialis Width $r=-0.404$

Relative Supinator Length $r=-0.144$

Geometric Mean $r=0.606$

Relative Olecranon Fossa Width $r=-0.301$

Relative Olecranon Fossa Width $r=0.739$

125868 = Lophocebus (84.3\%)

$56693=$ Mandrillus (88.2\%)

Geometric Mean $r=0.633$

Relative Olecranon Fossa Width $r=-0.353$
$56693=$ Cercocebus (89.5\%)

$56693=$ Cercocebus (98.2\%)

125868 = Lophocebus (59.1\%)

$56693=$ Mandrillus (99.4\%)

125868 = Papio $(95.2 \%)$

See Fig. 9b

See Fig. 9c

See Fig. 9d

${ }^{a}$ Cross-validation = percentage of specimens correctly classified during cross-validation procedure. Prior probabilities were calculated on the basis of group size (rather than assuming equal groups). UCMP 56693 and UCMP 125868 were kept out of the analyses as unknowns and then classified on the basis of the resulting discriminant function(s). For each analysis, Fossil Classification column lists the group to which each fossil specimen was classified post-hoc. C/M = Cercocebus/Mandrillus group, P/L = 
Papio/Lophocebus group. Number in parentheses = posterior probability of the specimen belonging to the given group. See also Figs. 8-9. 